\title{
Design Triggers for Excessive Online Video Clip Watching
}

\author{
Simon Kloker \\ Karlsruhe Institute of Technology \\ simon.kloker@kit.edu
}

\author{
Anke Greif-Winzrieth \\ Karlsruhe Institute of Technology \\ anke.greif-winzrieth@kit.edu
}

\begin{abstract}
Addiction in the context of information technology gained increased public interest within the last years. Only recently, companies like Apple, Google, or Instagram announced to fight "Smartphone Addiction" and integrated respective features into their systems. However, whether and how such features can help is still an open question. Currently, there is only a very rudimentary understanding of addictions in information systems ("IT-triggered disorders"). Even in clinical research, there is no consensus on the nature of such addictions yet. This work researches how design adaptations interfere with "Excessive Online Video Clip Watching”. We base our assumptions on the reinforcement cycle of disorder development and the Four-Component Model for Non-addictive Information Systems (4-NAIS). A study with 186 participants is conducted, indicating that linking findings from Psychology and Neurosciences to Information Systems is necessary to design information systems that can tackle the problem of "IT-triggered disorders".
\end{abstract}

\section{Introduction}

Since the omnipresence of information technology (IT) and online media (e.g. YouTube), a plethora of social phenomena occurs to us every day at train stations, universities, and even in our family life. People seem to be "addicted" to their smartphones, tablets, computers, or other information and entertainment systems - often leading to negative consequences in their daily lives, as they ignore important professional and personal duties [1]. "Twitteritis", "Selfitis", or "YouTube addiction" are terms that are regularly read in the newspapers [2], and their consequences are almost always described as problematic, e.g., by the World Health Organization (WHO) [3]. When asked about social media, former Facebook president Sean Parker put it like this: "God only knows what it's doing to our children's brains."
[4]. However, besides the individual risks, there are plenty of problems on a societal level. To name just a few, a study in the United States (U.S.) found that addiction to information systems reduces family time and burdens family life [5]. Another study in the U.S. found that distractions from social media cost the U.S. economy $\$ 650$ Mio. per year [6].

The literature identifies many different phenomena of this kind, however, currently, there is hardly any consensus regarding the existence of a real disorder, though there seems to be growing evidence, depending on the context and terminology $[2,7]$. Nevertheless, there is an urgent need to understand and address such "IT-triggered disorders" [e.g. 8], which is already done in some academic fields like Psychology or Neuroscience. The Information Systems (IS) discipline, though the matter is directly related to its object of research, is remarkably dormant except for some few authors. The findings of other disciplines have to be transferred back into the IS research to tackle the problem also by design interventions (and not only treatments or policies). "Successful intervention may be [...] more an issue of understanding the root and nature of the problem" instead of mere policy-making [8].

The current research aims to provide a model and first insights that help to transfer findings from Psychology and Neurosciences regarding the process of disorder development to identify where IT design can positively interfere. A study is conducted to test the effect of six design adaptions on "Excessive Online Video Clip Watching". Results indicate that the interaction of these design adaptations with the development of addictive behavior is rather based on a long process than on strong immediate effects and that the subjectively perceived situation, as well as individual risk factors, are of high importance (as suggested in the 4-NAIS Model, see Related Work). The rest of the paper is structured as follows: Related Work, introducing necessary concepts regarding IT-triggered disorders and motives to watch online 
video clips. Methodology, illustrating the experiment and measures, and defining the background of the performed study. Results, Discussion, and Conclusion to give the first insight into the potential contribution.

\section{Related Work}

\subsection{IT-triggered disorders, Addictive Cues, and Design}

In this paper, IT-triggered disorders are defined as behavioral disorders that involve excessive and compulsive use of IT despite significant negative consequences [9]. Several described phenomena, in part overlapping, are subsumed under this term $[1,10]$, though, the measures for these phenomena only overlap in part [11]. However, despite these differences, there are plausible reasons to subsume them under one term especially in the context of online experiments, such as similarities regarding the risk factors, the process of addiction development, or the symptoms [1, 12]. Also, they often describe similar behavior on different abstraction levels. Internet Addiction may include Social Network Site Addiction, which itself may include Online Communication Addiction. The current state of research does not allow for clear delimitation, which makes it reasonable to focus on documented similarities. The Four-component model for Non-addictive Information Systems (4-NAIS) [9], as an adaption of the Interaction of Person-Affect-Cognition-Execution (I-PACE) model [12] explains the relevant factors and their interaction with a focus on the development of Internet-use disorders. The I-PACE model illustrates which factors lead to the development of Internet Addiction (or Internet-use disorders) in their causal/chronological order. While it does not allow us to directly derive hypotheses for effects, it helps to understand the reinforcing nature of such addictions in general. The I-PACE model became used as a reference model in several subsequent research projects [e.g. 13-16]. The 4-NAIS model integrates the I-PACE model with the reinforcement cycle of disorder development [12] and maps classes of IS interventions to the place they interact with the process of disorder development. Among others, it is used by [17]. The four classes of IS interventions are (1) Situation Management, (2) Access Management/Decision Support, (3) Gratification Management, and (4) Expectation Management /Education. Situation Management adapts or suppresses addictive cues (e.g. "randomness" or "autoplay" [18]) or the subjectively perceived situation. Access Management/Decision Support ensures that the decision to use a technology or consume media is based on full information instead of the promise of "no instant cost". Gratification Management attenuates or suppresses the gratification of the system to inhibit positive conditioning. Finally, Expectation Management/Education is meant to reflect the (real) implications of using or consuming the system or service back to the user.

A large part of the discussion about which design features "make us hooked" or help us to oppose negative developments takes place in online forums and blog entries [e.g. 18, 19]. However, there are also some scientific publications. An experiment conducted in South Korea in the context of online video gaming showed that a "shut-down" policy after a certain time does more harm than good and drives a craving for more gaming [20]. Another study showed that warning messages can lead to Dual-Task Inference and therefore achieve rather counterproductive results [21]. Therefore, designing and integrating features that help to tackle the problem of "IT-triggered disorders" is no trivial endeavor and requires to be addressed profoundly. The use of nudges is especially discussed in the context of Social Network Addiction [22, 23].

\subsection{Excessive Online Video Clip Watching}

The current study is focusing on "Excessive Online Video Clip Watching". Though this behavior is widely known, as for many other disorders in information systems usage, there is no common definition. "YouTube Addiction" is described and researched by several authors [24, 25]. "YouTube Addiction", "Compulsive YouTube Use" or "YouTube stickiness" is assumed, when the user cannot limit their use [26]. However, in contrast to Internet Addiction, the use does not necessarily need to be associated with negative consequences for the user's lives [27]. YouTube is also regarded as a Social Network and therefore part of "Social Network Sites Addiction", "Social Media Disorder", or related disorders [24, 28]. Indeed, YouTube allows sharing, posting, and commenting on video clips and thus has a social component besides watching. It was shown that the share of "disordered" users is significantly higher among those who actively post comments than among those who just consume video clips [28]. Based on the Uses and Gratification Framework, motives for using Social Media can be divided into four categories [29]: Hedonic gratification, affection gratification, information gratification, and social gratification. Three of these categories can be found in YouTube use 
[26]. This also implies that there may be more than one path to the development of IT-triggered disorders. These multiple paths lead to a much larger complexity when trying to identify the effect of design features within the process of disorder development. Therefore, we exclude the social aspect of YouTube in the first instance as well as the information gratification and focus solely on hedonic motives.

Several distinguished hedonic motives leading to rather uncontrolled online video clip consumption can be identified, of which two are seen as backed with strong evidence. The first is "mood regulation". Humorous YouTube video clips have been found to reduce stress at the workplace in a U.S. based study among employees [30]. Another study provides evidence that Cat Videos are used to cope with negative affective emotional states and to maintain positive states [31]. Entertainment is also regarded as a motive for watching online video clips [26]. However, several sources regard entertainment as a means for mood regulation [30, 32]. The second motive is "procrastination". The study by Myrick [31] researched the effect of procrastination as a motive to watch video clips. As expected, procrastination raised "post-view guilt", but, otherwise hypothesized, also had a slight positive effect on enjoyment [31].

\section{Method}

Based on the considerations and context described in the sections above an online experiment is designed and conducted. In the experiment, participants are confronted with a humorous video clip [no. 14 from 33] followed by a control screen or one out of six treatment screens (stimuli) that contain a design feature based on one of the four dimensions from the 4-NAIS model. Previous research found that "security measures" are best placed after watching online video clips (instead of during the video clip) in order not to encounter Dual-Task Inference and thereby raising message disregard [21]. The control treatment shows a screen after the video clip (end screen) (T0) that more or less resembles the screen that YouTube shows after a video clip is finished ${ }^{1}$ (see Fig. 1). T0 will be considered the baseline treatment. T1 shows the same screen as T0, but with a removable overlay that contains an adapted version of the Breathing Exercises for Relaxation from the University of Michigan Health

\footnotetext{
${ }^{1}$ YouTube varies the end screens and they can also be customized by the video clip author. Unmodified screens vary from a suggestion of between 6 and 12 clips or a screen that starts a new clip after a short time.
}

Library [34]. Previous research showed that perceived stress mediates the addiction development process by reducing inhibitory control and raises susceptibility to addictive triggers $[35,36]$. Therefore, we hypothesize perceived stress to raise perceived gratification (dependent variable in the following regression, proxy for the development of an IT-triggered disorder). T2 is similar to $\mathrm{T} 1$, but the overlay shows some usage statistics. Usage statistics are the most frequently suggested (and implemented) measure against excessive use [37] and we therefore also hypothesize that it will reduce perceived gratification. T3 shows a screen that only allows replaying the same video clip. We hypothesize according to the 4-NAIS model that not offering alternating content would reduce perceived gratification. T4 is similar to $\mathrm{T} 1$, but the overlay shows a text that helps the participant to reflect on the last video. Previous research found that raising awareness for potential problems in Internet-use helps to prevent the development of IT-triggered disorders and not to inflate the experienced gratification [8]. We hypothesize $\mathrm{T} 4$ to reduce the perceived gratification. T5 immediately starts a new video clip. This was also found on YouTube recently. We hypothesize it to raise perceived gratification. T6 shows a black screen with an overlay, asking if the participant wants to see another video clip. This randomness is also suggested to raise gratification based on considerations from [18]. The treatments are summarized in Table 1.

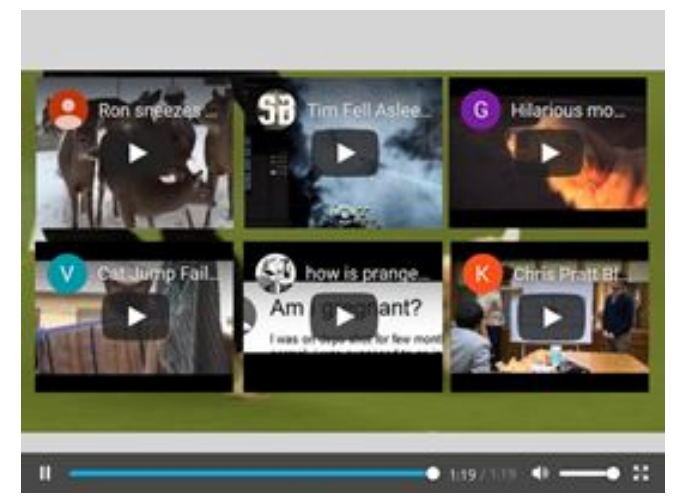

Figure 1. Default end screen (T0).

We elaborate on the moderating effect of these stimuli on relationships demonstrated by previous research. As independent variables, we consider known motives for online video clip watching and risk factors that are demonstrated to foster addictive tendencies. As dependent variables, we consider downstream constructs of the 4-NAIS model, such as perceived gratification, craving, inhibitory control, the decision to watch another clip, and an addiction scale. Further, we include some control variables that are relevant for the 
subjectively perceived situation in the I-PACE Model by Brand et al. [12] or other related work: Loneliness, Life satisfaction, Aggression, Procrastination, and Social Competence.

Table 1. Specific design features, classified according to the four components

\begin{tabular}{|c|c|}
\hline $\begin{array}{l}\text { Situation } \\
\text { Management }\end{array}$ & $\begin{array}{l}\left(\mathrm{T}_{1}\right) \text { Stress Management: Breathing } \\
\text { Exercises for Relaxation } \\
\left(\mathrm{T}_{5}\right) \text { Autoplay: Next video starts } \\
\text { immediately }\end{array}$ \\
\hline $\begin{array}{l}\text { Access } \\
\text { Management / } \\
\text { Decision Support }\end{array}$ & $\begin{array}{l}\left(\mathrm{T}_{2}\right) \text { Usage summary based on } \\
\text { previous answers and statistics on } \\
\text { average videos. }\end{array}$ \\
\hline $\begin{array}{l}\text { Gratification } \\
\text { Management }\end{array}$ & $\begin{array}{l}\left(\mathrm{T}_{3}\right) \text { Only the option to repeat the } \\
\text { clip (suppress alternating } \\
\text { gratification) } \\
\left(\mathrm{T}_{6}\right) \text { Only the option to watch a } \\
\text { new video, no preview } \\
\text { (Randomness) }\end{array}$ \\
\hline $\begin{array}{l}\text { Expectation } \\
\text { Management / } \\
\text { Education }\end{array}$ & $\begin{array}{l}\left(\mathrm{T}_{4}\right) \text { Reflection of the value added } \\
\text { by the video to one's development }\end{array}$ \\
\hline
\end{tabular}

Table 2. The sequence of screens in the experiment (from top to bottom)

\begin{tabular}{|c|c|}
\hline $\begin{array}{l}\text { Independent } \\
\text { Variables, } \\
\text { Controls }\end{array}$ & $\begin{array}{ll}\text { - } & \text { Online Video Clip Consumption } \\
\text { - } & \text { Time pressure } \\
\text { - } & \text { Stress level }\end{array}$ \\
\hline Framing & - Humorous Video \\
\hline $\begin{array}{l}\text { Stimulus } \\
\text { Specific }\end{array}$ & $\begin{array}{ll}\text { - } & \text { Design Feature (T0-T6) } \\
\text { - } & \text { Manipulation Check }\end{array}$ \\
\hline $\begin{array}{l}\text { Dependent } \\
\text { Variables }\end{array}$ & $\begin{array}{l}\text { - } \quad \text { Gratification (self-formulated) } \\
\text { - } \quad \text { Pxpectation (self-formulated) } \\
\text { Entertainment [38] } \\
\text { - } \\
\text { Process Gratification - Passing } \\
\text { Time [38] } \\
\text { The decision to watch further } \\
\text { clips (if applicable) }\end{array}$ \\
\hline $\begin{array}{l}\text { Independent } \\
\text { Variables } \\
\text { (Risk } \\
\text { Factors) }\end{array}$ & $\begin{array}{ll}- & \text { "Addiction” S-IAT [39] } \\
- & \text { Inhibitory Control [40] } \\
\text { - } & \text { Loneliness, ULCA [41] } \\
\text { - } & \text { Life satisfaction [42] } \\
\text { - } & \text { Social Competence [43] } \\
\text { - } & \text { Aggression [44] } \\
\text { - } & \text { Procrastination [45] }\end{array}$ \\
\hline Controls & - Demographics, Device \\
\hline
\end{tabular}

- General relation to the video clip topic

Table 2 illustrates the process of the experiment and specifies the measures (see Table 5 in the appendix). The broad focus of the dependent and independent variables is due to the explorative character of our study. The basic hypothesis is that T1-4 will rather reduce scores for dependent variables, while T5 and T6 will rather raise them. However, as stated above, there is no evidence yet.

The experiment was implemented in LimeSurvey (Version 3.7.1+180424). Some custom JavaScript was added to ensure that the end screen appeared seamlessly and naturally after the clip and that the clip had to be ended before the manipulation check $^{2}$ could be answered. 200 Participants, recruited using Prolific Academic (UK and US only), took part and were randomly assigned to one of the treatments (between-subjects). The survey was opened in three waves $(70,70,60)$ to avoid server overload. In the last wave, we did not offer T6 any longer, as the manipulation did not seem to work. 186 valid answers were collected. As exclusion criteria, we used two attention checks and excluded answers that stated problems with the video or sound. Answers with completion times below 6 min were also excluded. On average, the experiment took each participant $8 \mathrm{~min} 36$ $\sec (\mathrm{SD} 3 \mathrm{~min} 17 \mathrm{sec}$ ). There was a fixed payment of $£ 1$ (\$1.31), resulting in an average payment of $6.97 £ / h$ $(9.13 \$ / \mathrm{h})$. Before the experiment started, the participants were shown a welcome screen that briefly explained that participants have to watch a video clip and that we require them to have their device sound turned on (including the possibility for a sound-check).

\section{Results}

The inter-construct reliability of most of the reflective constructs was above the common minimum threshold of Cronbach's $\alpha$ of 0.7 : Gratification $(\alpha=$ $0.90)$; Expectation $(\alpha=0.87)$; Process Gratification $(\alpha$ $=0.77)$; S-IAT $(\alpha=0.88)$; Life Satisfaction $(\alpha=0.92)$; Loneliness $(\alpha=0.89)$; Procrastination $(\alpha=0.68)$. To test formative construct reliability, tests for multicollinearity were performed by examining the variance inflation factor (VIF, should be below 3.3) of the items. The VIF scores for all of the items did not exceed 1.27, demonstrating adequate construct

\footnotetext{
${ }^{2}$ Single item question to check whether the participant received the screen as intended to "make him watch more" video clips
} 
reliability [46]: Social Competence $(\max (\mathrm{VIF})<1.27)$; Inhibitory Control $(\max (\mathrm{VIF})<1.22)$; Aggression $(\max (\mathrm{VIF})<1.27)$. The validity of the (sometimes gratification (fulfilling of motives). A significant regression equation (however, with limited predictive

Table 3. Scores for the Dependent Variables (relative to T0)

\begin{tabular}{l|lllllll}
\hline & $\boldsymbol{T}_{\boldsymbol{0}}$ & $\boldsymbol{T}_{\mathbf{1}}$ & $\boldsymbol{T}_{\mathbf{2}}$ & $\boldsymbol{T}_{3}$ & $\boldsymbol{T}_{\mathbf{4}}$ & $\boldsymbol{T}_{\mathbf{5}}$ & $\boldsymbol{T}_{6}$ \\
\hline N & 37 & 32 & 22 & 25 & 32 & 24 & 14 \\
Manipulation & 3.28 & -0.00 & -0.64 & -0.15 & +0.12 & $\mathbf{+ 1 . 9 4 * * *}$ & -0.11 \\
$\begin{array}{l}\text { Check } \\
\text { Gratification }\end{array}$ & 19.32 & +0.52 & +0.58 & +1.00 & $\mathbf{+ 1 . 9 6 *}$ & $\mathbf{+ 2 . 2 2 .}$ & +0.24 \\
Expectation & 17.22 & -0.47 & -0.67 & +1.38 & $\mathbf{+ 1 . 6 .}$ & +1.03 & +0.14 \\
$\begin{array}{l}\text { Process Grat. } \\
\text { Clicked for further }\end{array}$ & 14.24 & +0.76 & -0.15 & +1.16 & $\mathbf{+ 1 . 6 6 *}$ & +1.38 & +0.9 \\
clip & & +4 & +0 & +5 & +3 & +2 & -1 \\
\hline
\end{tabular}

Table 4. Regression models on process gratification with alternating moderators.

\begin{tabular}{l|llllll}
\hline $\begin{array}{l}\text { Moderator } \\
(M)\end{array}$ & & Inhibition & Loneliness & $\begin{array}{l}\text { Life } \\
\text { satisfaction }\end{array}$ & S-IAT & $\begin{array}{l}\text { Procras- } \\
\text { tination }\end{array}$ \\
\hline Intercept & $17.22^{* * *}$ & $10.36^{*}$ & $19.07^{* * *}$ & $15.39^{* * *}$ & $19.74^{* * *}$ & $21.23^{* * *}$ \\
$\mathrm{~T}_{4}$ & $\mathbf{1 . 6 0 .}$ & $\mathbf{1 3 . 2 3} *$ & 3.28 & 1.38 & -1.37 & -2.61 \\
$\mathrm{~T}_{5}$ & 1.04 & $\mathbf{1 0 . 0 0 .}$ & -4.40 & $\mathbf{7 . 9 9 *}$ & $\mathbf{- 6 . 2 2 .}$ & $\mathbf{- 6 . 7 8 .}$ \\
$M$ & & 0.36 & -0.13 & 0.09 & -0.08 & $\mathbf{- 2 . 7 8 .}$ \\
$\mathrm{T}_{4} * M$ & & $-\mathbf{0 6 2}$. & -0.14 & -0.00 & 0.10 & 0.29 \\
$\mathrm{~T}_{5} * M$ & & -0.48 & $\mathbf{0 . 4 1 *}$ & $\mathbf{- 0 . 3 2 *}$ & $\mathbf{0 . 2 3 *}$ & $\mathbf{0 . 5 5}$ \\
\hline Adj. $\mathrm{R}^{2}$ & 0.01 & 0.02 & 0.06 & 0.05 & 0.04 & 0.04 \\
$\mathrm{p}$ & 0.19 & 0.22 & 0.06 & 0.08 & 0.13 & 0.13 \\
\hline
\end{tabular}

shortened measures) was not re-validated, though it is to be expected that it is still given.

Table 3 briefly summarizes the scores for each treatment (T1-6 are shown in relative numbers to T0). Significant values are highlighted with bold font. Interestingly, only two treatments showed significant deviations at all. In T5 (autoplay), participants reported that they received more gratification from the video. Besides, they reported that the screen made them rather watch more videos. This, however, is hard to interpret for the autoplay feature specifically. T4 (a reflection of the clip) significantly raised perceived gratification and expectations for further clips. These effects point towards the opposite direction than hypothesized.

T6, turning out not to have significant effects does not mean that randomness does not trigger craving at all. T0, the standard screen currently used, e.g. by YouTube, was already designed to induce craving. The effect was, however, not larger. We cannot yet explain why some of the regulating treatments did not show significant effects. This may still be due to Dual-Task Inference, as the setting of "answering the survey questions" may also have required cognitive resources.

A multiple linear regression was performed to estimate the effect of the risk factors on the process ower) was found ( $\mathrm{df}=179, \mathrm{R} 2=0.02$ ) which only showed the addiction score as a slightly significant $(\mathrm{p}=$ $0.058)$ predictor. The gratification of the clip is therefore not influenced by risk factors to a large extent.

For the two treatments that turned out significant, we performed moderator analyses for the effect of the treatment on the expectation for another video. Table 4 reports the respective results of the six models. As a rather consistent finding, we see that moderation was (besides of Inhibition as moderator) only existent for the autoplay treatment. Though the explanatory value remained on a low level, the effects constantly point to the direction hypothesized, supporting its existence. The moderating effect of Loneliness and Life satisfaction in T5 may also point towards an increased decision inertia when the overall mental state is rather negative. Aggression and Social Competence did not seem to moderate the expectations and were therefore not reported in the table.

\section{Discussion and Conclusion}

The explorative study helped us to better understand several aspects of design adaptations 
interfere with "Excessive Online Video Clip Watching" and how to research these phenomena. First, the effects of the proposed design adaptations were rather small. This is not a problem for the theory, as we talk of a process of positive conditioning, that "lives" based on small effects. However, to study these effects, long-term observations are inevitable. Second, the direction of effects (of the design features) is less predictable than expected. This may be due to the special setting (survey) and may change in long-term observation. However, this higher complexity has to be reflected in further studies. Third, risk factors moderate these effects in the hypothesized direction. This emphasizes the role of adaptive information systems that can assess the current risk and adapt accordingly.

As expected, T4 (autoplay) raises the perceived gratification and at least may suggest that YouTube introduced this feature for the reason to raise the stickiness of its users. The positive effects of T5 contradict the argumentation of Kwon et al. [8], however, it may be necessary to first validate the text for reflection with experts. This may provide valuable insights, why the reflection leads to even more gratification. Several treatments did not turn out significant. We suggest that this is due to the control treatment selection, which resembled the YouTube screen. This probably resulted in small contrasts.

Further limitations of the current work are mainly due to the setting (online, flat fee incentive, one point of time) and also to the use of yet not pre-validated stimuli and measures. The construct for inhibitory control did not match the minimum threshold reliability. We cannot exclude that our results are subject to a self-assessment bias. Scales to measure addiction or inhibitory control are often also assessed by a third person (like parents) to reduce this bias [47]. Especially inhibitory control is often not assessed by questions, but with certain tasks (e.g. the Start-Stop Task, [47]). Further research may first address the limitations of this study (also including the limited number of participants) and implement long-term experiments. Also, further data sources and measurement methods may be included. One option would be the measurement of mouse movement or other usage measures to support the diagnosis of risk factors [21]. Better and further design features also need to be theoretically founded and evaluated. Privacy and data sovereignty and ethical considerations regarding such solutions need to be addressed more in-depth as well $[17,48]$.

In a next step, it would be fruitful to link these findings to research regarding other platforms. We chose YouTube, as we could expect all participants to be familiar with its use. However, current apps like TikTok, Quibi, and Twitch seem to attract and bind especially younger and prone people much stronger. TikTok and Quibi also would also be interesting, as it is to assume that they develop addictions faster, as they also incorporate the element of reciprocity (see 4-NAIS Model component "Expectation Management $[9,18]$ ). One further interesting point would be to elaborate what gratification users derive from reengineering the algorithms behind platforms. Bucher (2017) [50] calls this phenomenon "algorithmic imaginary" and it is well conceivable that users show continued usage not because of the content itself, but to understand what is suggested to them by the algorithm (and indirectly by the crowd). Resulting effects, demonstrated for Facebook, may also exist in other platforms and interact with the development of IT-triggered disorders. Finally, it may be interesting to use Citizen Science approaches in researching IT-triggered disorders [51]. Users may report what they observe in their families or (online) communities, as the apps and services on the internet are changing very fast and one platform may be replaced by another very quickly (e.g. YouTube and Twitch).

Research should aim towards a complete understanding of the triggers and processes behind IT-triggered disorders to tackle the problem and build "Non-addictive Information Systems". The urgent need is undeniable. This work provided the first insight into the effect of design on the reinforcement cycle of disorder development and by this opens the transfer of findings from psychology to the prevention of IT-triggered disorder development from an information system design perspective.

\section{References}

[1] Vaghefi, I., Lapointe, L., Boudreau-Pinsonneault, C.: A typology of user liability to IT addiction. Inf. Syst. J. 27, 125-169 (2017). https://doi.org/10.1111/isj.12098.

[2] Starcevic, V., Billieux, J., Schimmenti, A.: Selfitis, selfie addiction, Twitteritis: Irresistible appeal of medical terminology for problematic behaviours in the digital age. Aust. N. Z. J. Psychiatry. 52, 408-409 (2018). https://doi.org/10.1177/0004867418763532.

[3] World Health Organization: Public Health Implications of Excessive Use of the Internet, Computers, Smartphones and Similar Electronic Devices Meeting report, Main Meeting Hall, Foundation for Promotion of Cancer Research, National Cancer Research Centre, Tokyo, Japan, 27-29 Augus. (2015).

[4] Silverman, E.: Facebook's first president, on Facebook: "God only knows what it's doing to our children's brains," https:/www.washingtonpost.com/news/ the-switch/wp/2017/11/09/facebooks-first-president-on-fa 
cebook-god-only-knows-what-its-doing-to-our-childrensbrains $/$ ?noredirect $=$ on\&utm term $=.41 \mathrm{dec} 403 \mathrm{cc} 7 \mathrm{c}$.

[5] Common Sense Media: TECHNOLOGY ADDICTION: concern, controversy and finding balance (Executive Summary May 2016), https://www.commonsensemedia. org/sites/default/files/uploads/research/2016_csm_techno logy_addiction_executive_summary.pdf, (2016).

[6] Shore, J.: Social Media Distractions Cost U.S. Economy $\$ 650 \quad$ Billion, http://mashable.com/2012/11/02/ social-media-work-productivity/\#P.XnaeAm8Eqx.

[7] Kuss, D.J., Griffiths, M.D., Karila, L., Billieux, J.: Internet Addiction: A Systematic Review of Epidemiological Research for the Last Decade. Curr. Pharm. Des. 20, 4026-4052 (2014). https://doi.org/10.2174/13816128113199990617.

[8] Kwon, H.E., So, H., Han, S.P., Oh, W.: Excessive dependence on mobile social apps: A rational addiction perspective. Inf. Syst. Res. 27, 919-939 (2016). https://doi.org/10.1287/isre.2016.0658.

[9] Kloker, S.: Non-Addictive Information Systems. Inf. Syst. Front. 22, 549-562 (2020). https://doi.org/10.1007/s10796-020-10011-w.

[10] Turel, O., Serenko, A., Giles, P.: Integrating Technology Addiction and Use: An Empirical Investigation of Online Auction Users. MIS Q. 35, 1043-1061 (2011).

[11] Kwon, M., Lee, J.Y., Won, W.Y., Park, J.W., Min, J.A., Hahn, C., Gu, X., Choi, J.H., Kim, D.J.: Development and Validation of a Smartphone Addiction Scale (SAS). PLoS One. https://doi.org/10.1371/journal.pone.0056936.

[12] Brand, M., Young, K.S., Laier, C., Wölfling, K., Potenza, M.N.: Integrating psychological and neurobiological considerations regarding the development and maintenance of specific Internet-use disorders: An Interaction of Person-Affect-Cognition-Execution (I-PACE) model. Neurosci. Biobehav. Rev. 71, 252-266 (2016). https://doi.org/10.1016/j.neubiorev.2016.08.033.

[13] Oberst, U., Wegmann, E., Stodt, B., Brand, M., Chamarro, A.: Negative consequences from heavy social networking in adolescents: The mediating role of fear of missing out. J. Adolesc. 55, 51-60 (2017). https://doi.org/10.1016/j.adolescence.2016.12.008.

[14] Weinstein, A., Livny, A., Weizman, A.: New developments in brain research of internet and gaming disorder. Neurosci. Biobehav. Rev. 75, 314-330 (2017). https://doi.org/10.1016/j.neubiorev.2017.01.040.

[15] Duke, É., Montag, C.: Smartphone addiction, daily interruptions and self-reported productivity. Addict. Behav. Reports. 6, 90-95 (2017). https://doi.org/10.1016/j.abrep.2017.07.002.

[16] He, Q., Turel, O., Bechara, A.: Brain anatomy alterations associated with Social Networking Site (SNS) addiction. Sci. Rep. 7, 1-8 (2017). https://doi.org/10.1038/srep45064.

[17] Kloker, S., Riegel, M.L., Weinhardt, C.: Sensible or too Sensitive? Do Privacy Concerns Hinder the Acceptance of Digital Solutions to Treat Smartphone Addiction? In: Proceedings of the 2020 IEEE 22nd Conference on
Business Informatics (CBI). pp. 10-19 (2020). https://doi.org/10.1109/CBI49978.2020.10053.

[18] Knorr, C.: The Sneaky Science Behind Your Kid's Tech Obsessions | Common Sense Media, https://www.commonsensemedia.org/blog/the-sneaky-sci ence-behind-your-kids-tech-obsessions.

[19] Harris, T.: How Technology is Hijacking Your Mind from a Former Insider | Medium.com, https://medium.com/thrive-global/how-technology-hijack s-peoples-minds-from-a-magician-and-google-s-design-et hicist-56d62ef5edf3.

[20] Davies, B., Blake, E.: Evaluating existing strategies to limit video game playing time. IEEE Comput. Graph. Appl. 36, 47-57 (2016). https://doi.org/10.1109/MCG.2016.25.

[21] Jenkins, J.L., Anderson, B.B., Vance, A., Kirwan, C.B., Eargle, D.: More harm than good? How messages that interrupt can make us vulnerable. Inf. Syst. Res. 27, 880-896 (2016). https://doi.org/10.1287/isre.2016.0644.

[22] Purohit, A.K., Barclay, L., Holzer, A.: Designing for Digital Detox: Making Social Media Less Addictive with Digital Nudges. In: CHI '20 Extended Abstracts, April 25-30, 2020, Honolulu, HI, USA. pp. 1-9 (2020). https://doi.org/10.1145/3334480.3382810.

[23] Okeke, F., Sobolev, M., Dell, N., Estrin, D.: Good vibrations: Can a digital nudge reduce digital overload? In: Proceedings of the MobileHCI 2018 - International Conference on Human-Computer Interaction with Mobile Devices and Services. pp. 4:1-4:12 (2018). https://doi.org/10.1145/3229434.3229463.

[24] Balakrishnan, J., Griffiths, M.D.: Social media addiction: What is the role of content in YouTube? J. Behav. Addict. 6, 364-377 (2017). https://doi.org/10.1556/2006.6.2017.058.

[25] Chiang, H.-S., Hsiao, K.-L.: YouTube stickiness: the needs, personal, and environmental perspective. Internet Res. 25, 85-106 (2015). https://doi.org/10.1108/ IntR-11-2013-0236.

[26] Klobas, J.E., McGill, T.J., Moghavvemi, S., Paramanathan, T.: Compulsive YouTube usage: A comparison of use motivation and personality effects. Comput. Human Behav. 87, 129-139 (2018). https://doi.org/10.1016/j.chb.2018.05.038.

[27] Kuss, D.J., Billieux, J.: Technological addictions: Conceptualisation, measurement, etiology and treatment. Addict. Behav. 64, 231-233 (2017). https://doi.org/10.1016/j.addbeh.2016.04.005.

[28] van den Eijnden, R.J.J.M., Lemmens, J.S., Valkenburg, P.M.: The Social Media Disorder Scale. Comput. Human Behav. 61, 478-487 (2016). https://doi.org/10.1016/j.chb.2016.03.038.

[29] Gan, C.: Gratifications for using social media: A comparative analysis of Sina Weibo and WeChat in China. Inf. Dev. 34, 139-147 (2018). https://doi.org/10.1177/0266666916679717.

[30] Janicke-Bowles, S.H., Rieger, D., Connor, W.: Finding Meaning at Work: The Role of Inspiring and Funny YouTube Videos on Work-Related Well-Being. J. Happiness Stud. 20, 1-22 (2018). https://doi.org/10.1007/s10902-018-9959-1. 
[31] Myrick, J.G.: Emotion regulation, procrastination, and watching cat videos online: Who watches Internet cats, why, and to what effect? Comput. Human Behav. 52, $168-176$

(2015). https://doi.org/10.1016/j.chb.2015.06.001.

[32] Khan, M.L.: Social media engagement: What motivates user participation and consumption on YouTube? Comput. Human Behav. 66, 236-247 (2017). https://doi.org/10.1016/j.chb.2016.09.024.

[33] Piedra, X.: Behold, 20 of the funniest YouTube videos ever, $\quad \mathrm{https}: / /$ mashable.com/article/funny-youtubevideos-reddit/?europe=true\#F8euZ_ZqZiqp.

[34] Healthwise Staff: Stress management: breathing exercises for relaxation, https://www.uofmhealth.org/health-library/uz2255.

[35] Samaha, M., Hawi, N.: Relationships among smartphone addiction, stress, academic performance, and satisfaction with life. Comput. Human Behav. 57, 321-325 (2016). https://doi.org/10.1016/j.chb.2015.12.045.

[36] Chiu, S.I.: The relationship between life stress and smartphone addiction on taiwanese university student: A mediation model of learning self-Efficacy and social self-Efficacy. Comput. Human Behav. 34, 49-57 (2014). https://doi.org/10.1016/j.chb.2014.01.024.

[37] van Velthoven, M.H., Powell, J., Powell, G.: Problematic smartphone use: Digital approaches to an emerging public health problem. Digit. Heal. 4, 205520761875916 https://doi.org/10.1177/2055207618759167.

(2018)

[38] Liu, I.L.B., Cheung, C.M.K., Lee, M.K.O., Liu, I.L.B.; Understanding Twitter Usage: What Drive People Continue to Tweet. In: PACIS 2010 Proceedings. pp. 928-941 (2010).

[39] Pawlikowski, M., Altstötter-Gleich, C., Brand, M.: Validation and psychometric properties of a short version of Young's Internet Addiction Test. Comput. Human Behav. 29, 1212-1223 (2013). https://doi.org/10.1016/j.chb.2012.10.014.

[40] Ellis, L.K., Rothbart, M.K.: Revision of the Early Adolescent Temperament Questionnaire. In: Biennial meeting of the Society for Research in Child Development 2001, Minneapolis (Poster) (2001).

[41] Russell, D.: UCLA Loneliness Scale Version 3 (description of Measure). J. Pers. Soc. Psychol. 39, 3-4 (1996). https://doi.org/10.1207/s15327752jpa6601.

[42] Diener, E., Emmons, R.A., Larsen, R.J., Griffin, S.: The Satisfaction With Life Scale. J. Personal. Assessment, 49, 71-75 https://doi.org/10.1207/s15327752jpa4901 13.

[43] Buhrmester, D., Furman, W., Wittenberg, M.T., Reis, H.T.: Five Domains of Interpersonal Competence in Peer Relationships. J. Pers. Soc. Psychol. 55, 991-1008 (1988). https://doi.org/10.1037/0022-3514.55.6.991.

[44] Buss, A.H., Perry, M.: The Aggression Questionnaire. J. Pers. Soc. Psychol. 63, 452-459 (1992).

[45] Lay, C.H.: At last, my research article on procrastination.Journal of Research in Personality. J. Res. Pers. 20, 474-495 (1986).
[46] Petter, Straub, Rai: Specifying Formative Constructs in Information Systems Research. MIS Q. 31, 623 (2007). https://doi.org/10.2307/25148814.

[47] Enticott, P.G., Ogloff, J.R.P., Bradshaw, J.L.: Associations between laboratory measures of executive inhibitory control and self-reported impulsivity. Pers. Individ. Dif. 41, 285-294 (2006). https://doi.org/10.1016/j.paid.2006.01.011.

[48] Peukert, C., Kloker, S.: Trustworthy AI: How Ethicswashing Undermines Consumer Trust. In: Proceedings of the 15th International Conference on Wirtschaftsinformatik, Potsdam, Germany (2020). https://doi.org/10.30844/wi_2020_j11-peukert.

[49] Stodt, B., Brand, M., Sindermann, C., Zhou, M., Sha, P., Montag, C.: Investigating the Effect of Personality, Internet Literacy, and Use Expectancies in Internet-Use Disorder: A Comparative Study between China and Germany. Int. J. Environ. Res. Public Health. 15, 579-606 (2018). https://doi.org/10.3390/ijerph15040579.

[50] Bucher, T.: The algorithmic imaginary: exploring the ordinary affects of Facebook algorithms. Information Communication and Society,20(1), 30-44 (2017). https://doi.org/10.1080/1369118X.2016.1154086

[51] Weinhardt, C., Kloker, S., Hinz, O., \& van der Aalst, W. M. P.: Citizen Science in Information Systems Research. Business \& Information Systems Engineering 61(4) (2020). https://doi.org/10.1007/s12599-020-00663-y 


\section{Appendix}

Table 5. Items and Scales for the survey part of the online experiment.

\begin{tabular}{|c|c|}
\hline $\begin{array}{l}\text { Process Gratification Entertainment } \\
\text { [adapted from 38] }\end{array}$ & \\
\hline $\begin{array}{l}\text { Please answer the following questions } \\
\text { spontaneously and truthfully. There are } \\
\text { no wrong answers. } \\
\text { - PGP1: Watching the video clip } \\
\text { enjoyed me. } \\
\text { PGP2: Watching the video clip } \\
\text { entertained me. }\end{array}$ & $\begin{array}{l}1=\text { completely } \\
\text { false, } \\
2=\text { false, } \\
3=\text { neutral, } \\
4=\text { true, } \\
5=\text { completely } \\
\text { true }\end{array}$ \\
\hline $\begin{array}{l}\text { Process Gratification Passing Time } \\
\text { [adapted from 38] }\end{array}$ & \\
\hline $\begin{array}{l}\text { Please answer the following questions } \\
\text { spontaneously and truthfully. There are } \\
\text { no wrong answers. } \\
\text { - PGE1: Watching the video clip } \\
\text { helped me pass the time. } \\
\text { PGE2: Watching the video was } \\
\text { the best thing to do for the } \\
\text { moment (nothing better to do } \\
\text { right now). }\end{array}$ & $\begin{array}{l}1=\text { completely } \\
\text { false, } \\
2=\text { false, } \\
3=\text { neutral, } \\
4=\text { true, } \\
5=\text { completely } \\
\text { true }\end{array}$ \\
\hline \multicolumn{2}{|l|}{ Gratification (self-formulated) } \\
\hline $\begin{array}{l}\text { Please answer the following questions } \\
\text { spontaneously and truthfully. There are } \\
\text { no wrong answers. } \\
\text { - GRAT1: I liked watching the } \\
\text { video clip. } \\
\text { - GRAT2: I enjoyed watching } \\
\text { the video clip. } \\
\text { - GRAT3: Watching the video } \\
\text { clip reduced my stress level. } \\
\text { - GRAT4: I think, the video clip } \\
\text { was worthwhile watching. } \\
\text { GRAT5: I think, the video clip } \\
\text { was funny. }\end{array}$ & $\begin{array}{l}1=\text { completely } \\
\text { false, } \\
2=\text { false, } \\
3=\text { neutral, } \\
4=\text { true, } \\
5=\text { completely } \\
\text { true }\end{array}$ \\
\hline Expectation (self-formulated) & \\
\hline
\end{tabular}

Please answer the following questions spontaneously and truthfully. There are no wrong answers.

- EXP1: I would like to watch another video clip.

- EXP2: I would enjoy watching a further video clip.

- EXP3: I expect, watching a further video clip would reduce my stress level.

- EXP4: I expect, watching a further video clip would be worthwhile.

- EXP5: I expect, a further video clip would be funny.

\begin{tabular}{|c|c|}
\hline $\begin{array}{l}\text { Short version of Young's Internet } \\
\text { Addiction Test [39] }\end{array}$ & \\
\hline No changes & \\
\hline $\begin{array}{l}\text { UCLA Loneliness Scale } 3 \text { [top } 5 \text { items } \\
\text { from 41] }\end{array}$ & \\
\hline $\begin{array}{l}\text { The following statements describe how } \\
\text { people sometimes fell. For each } \\
\text { statement, please indicate how often you } \\
\text { feel the way described. } \\
\text { - L1: How often do you feel that } \\
\text { there is no one you can turn to? } \\
\text { - L2: How often do you feel that } \\
\text { no one really knows you well? } \\
\text { L3: How often do you feel } \\
\text { isolated from others? } \\
\text { L4: How often do you feel that } \\
\text { there are people who really } \\
\text { understand you? (R) } \\
\text { L5: How often do you feel } \\
\text { alone? }\end{array}$ & $\begin{array}{l}1=\text { never, } \\
2=\text { rarely, } \\
3=\text { sometimes } \\
\quad 4=\text { often, } \\
5=\text { very often }\end{array}$ \\
\hline $\begin{array}{l}\text { Social Competence Subscale [top } 5 \\
\text { items from 43] }\end{array}$ & \\
\hline
\end{tabular}




\begin{tabular}{|c|c|}
\hline $\begin{array}{l}\text { The statements below describe situations } \\
\text { in interpersonal encounters. Please select } \\
\text { the most appropriate answer when } \\
\text { thinking of yourself. } \\
\text { - I21: Introducing yourself to } \\
\text { someone you might like to get } \\
\text { to know (or date). } \\
\text { A32: Telling a companion that } \\
\text { he or she has done something to } \\
\text { hurt your feelings. } \\
\text { D8: Confiding in a new } \\
\text { friend/date and letting him or } \\
\text { her see your softer, more } \\
\text { sensitive side. } \\
\text { E19: Helping a close } \\
\text { companion cope with family or } \\
\text { roommate problems. } \\
\text { C25: Refraining from saying } \\
\text { things that might cause a } \\
\text { disagreement to build into a big } \\
\text { fight. }\end{array}$ & $\begin{array}{l}\text { 1=poor, } \\
2=\text { fair, } \\
3=\mathrm{OK}, \\
4=\text { good, } \\
5=\text { extremely } \\
\text { good (answer } \\
\text { options were } \\
\text { explained } \\
\text { more } \\
\text { detail) in }\end{array}$ \\
\hline \multicolumn{2}{|l|}{ Life Satisfaction Scale [42] } \\
\hline \multicolumn{2}{|l|}{ No changes } \\
\hline \multicolumn{2}{|l|}{ Aggression Scale [top 4 items from 44] } \\
\hline $\begin{array}{l}\text { Please rate each item of the following list } \\
\text { regarding yourself. } \\
\text { - } \\
\text { PA2: Given enough } \\
\text { provocation, I may hit another } \\
\text { person. } \\
\text { VA1: I tell my friends openly } \\
\text { when I disagree with them. } \\
\text { A7: I have trouble controlling } \\
\text { my temper. } \\
\text { H7: I sometimes feel that } \\
\text { people are laughing at me } \\
\text { behind my back. }\end{array}$ & $\begin{array}{l}1=\text { extremely } \\
\text { uncharacteris } \\
\text { tic of me, } \\
2=\text { =ucharacte } \\
\text { ristic of me, } \\
3=\text { neither } \\
\text { uncharacteris } \\
\text { tic nor } \\
\text { characteristic } \\
\text { of me, } \\
4=\text { characteris } \\
\text { tic of me, } \\
5=\text { extremely } \\
\text { characteristic } \\
\text { of me }\end{array}$ \\
\hline Procrastination [selected items from 45] & \\
\hline
\end{tabular}

\begin{tabular}{|c|c|}
\hline $\begin{array}{l}\text { Please rate each item of the following list } \\
\text { regarding yourself. } \\
\text { - P1: I often find myself } \\
\text { performing tasks that I had } \\
\text { intended to do days before. } \\
\text { - P2: I do not do assignments } \\
\text { until just before they are to be } \\
\text { handed in. } \\
\text { - P8: I usually make decisions as } \\
\text { soon as possible. (R) } \\
\text { P15: I often have a task } \\
\text { finished sooner than necessary. } \\
\text { (R) } \\
\text { P16: I always seem to end up } \\
\text { shopping for birthday or } \\
\text { Christmas gifts at the last } \\
\text { minute. }\end{array}$ & $\begin{array}{l}1=\text { extremely } \\
\text { uncharacteris } \\
\text { tic of me, } \\
2=\text { uncharacte } \\
\text { ristic of me, } \\
3=\text { neither } \\
\text { uncharacteris } \\
\text { tic nor } \\
\text { characteristic } \\
\text { of me, } \\
4=\text { characteris } \\
\text { tic of me, } \\
5=\text { extremely } \\
\text { characteristic } \\
\text { of me }\end{array}$ \\
\hline $\begin{array}{l}\text { Inhibitory } \quad \text { Control } \\
\text { self-reported) [adapted from } 40]\end{array}$ & \\
\hline $\begin{array}{l}\text { Please rate each item of the following list } \\
\text { regarding yourself. } \\
\text { - IC10: It's hard for me not to } \\
\text { click on the next video clip } \\
\text { before I'm supposed to. (R) } \\
\text { - IC14: When someone tells me } \\
\text { to stop watching video clips, it } \\
\text { is easy for me to stop. } \\
\text { IC26: The more I try to stop } \\
\text { myself from doing something I } \\
\text { shouldn't, the more likely I am } \\
\text { to do it. (R) } \\
\text { IC43: It's easy for me to keep a } \\
\text { secret. } \\
\text { IC63: I can stick with my plans } \\
\text { and goals. }\end{array}$ & $\begin{array}{l}1=\text { extremely } \\
\text { uncharacteris } \\
\text { tic of me, } \\
2=\text { uncharacte } \\
\text { ristic of me, } \\
3=\text { neither } \\
\text { uncharacteris } \\
\text { tic nor } \\
\text { characteristic } \\
\text { of me, } \\
4=\text { characteris } \\
\text { tic of me, } \\
5=\text { extremely } \\
\text { characteristic } \\
\text { of me }\end{array}$ \\
\hline
\end{tabular}

